INTERNATIONAL JOURNAL OF SYSTEMATIC BACTERIOLOGY

Vol. 20, No. 3 July 1970

Page 334

Copyright 1970, Iowa State University Press

\title{
MYCOBACTERIUM BOVIS
}

\section{A SPECIES NAME IN SEARCH OF AN AUTHOR}

\author{
R. E. Buchanan
}

\begin{abstract}
A statement of the alternatives in determination of the correct citation of the authorship of the name of the bacterial species Mycobacterium bovis.
\end{abstract}

The Judicial Commission of the International Committee on Nomenclature of Bacteria has suggested that there may be some question as to the authorship of the proposal to accept the name of the species Mycobacterium bovis in the seventh edition of Bergey's Manual of Determinative Bacteriology. Karlson and Lessel have published a request for an Opinion recognizing that their proposal (P. 273, this issue of the I. J. S. B.) is the first that has been validly published.

Rule $15 \mathrm{a}$ of the International Code of Nomenclature states that the name of a taxon is not validly published if it does not indicate the name of the author. The author cited in the Manual is Bergey et al. with a reference to Mycobacterium tuberculosis var. bovis Bergey et al. 1934, 537. Karlson and Lessel are evidently correct in rejecting the name as not validly published.

It should be noted, however, that there is much internal evidence that Dr. G. B. Reed of Queens University, Kingston, Ontario, edited and revised the manuscripts for the 5th, 6th and 7th editions of the Bergey's Manual. In each edition there is a footnote to the description of the genus Mycobacterium stating that there had been complete revision.

The Judicial Commission is asked to decide whether there was an editorial lapsus calami for which the author was not responsible, or that he was responsible in not publishing the name as a combinatio nova. The name of the next species following Mycobacterium bovis in the 7 th edition is cited as Mycobacterium microti Reed, nom. nov. 